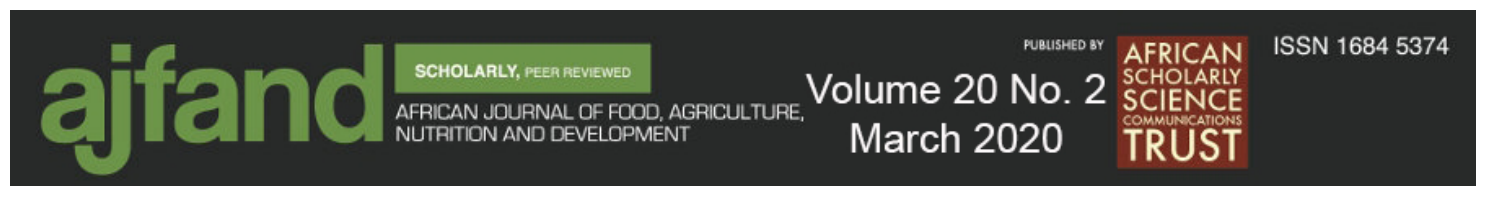

Afr. J. Food Agric. Nutr. Dev. 2020; 20(2): 15660-15676

DOI: 10.18697/ajfand.90.18925

\title{
PILOTING A COMMERCIAL BROILER PRODUCTION MODEL FOR SMALLHOLDERS IN RWANDA
}

Gill $T^{1 *}$, Urban $E^{2}$, Ader $D^{1}$, Nisengwe $R^{1}$ and $E$ Garner ${ }^{1}$

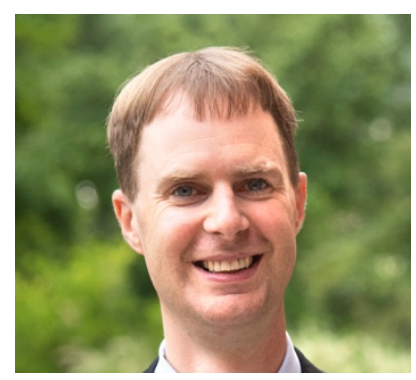

Tom Gill

*Corresponding author. Email: tomgill@utk.edu

${ }^{1}$ University of Tennessee Institute of Agriculture, Smith International Center, 2640 Morgan Circle Drive, Knoxville, TN 37996 USA

${ }^{2}$ Cornell University, Soil and Crop Sciences, 232 Emerson Hall, Ithaca, NY 14853 USA 


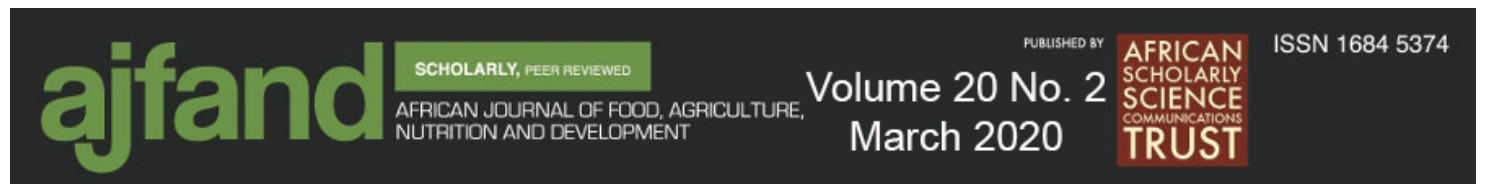

\begin{abstract}
Increasing food security is premised on improving economic empowerment as well as nutrition across the household. As such, development projects across Africa are integrating nutrition objectives into pro-poor value chain development interventions to increase dietary diversity and incomes. To meet the micronutrient demands of a growing population, Rwanda seeks to increase the production of and access to meat-based proteins, including chicken production. Despite Rwanda's recent rapid economic growth, there is a limited supply of and access to animal-sourced protein nationally. A hybrid broiler model, which integrates elements of smallholder and larger intensive poultry models, could be a sustainable approach. A model piloted in Musanze District, Rwanda. Tworore Inkoko, Twunguke (TI) (Let's raise chickens for profit!) uses an intensive, 100bird model with the aim of training and supporting 750 smallholder farmers through an innovative private-sector-based train-the-trainer approach. This study examines the initial evidence from TI production data to determine (a) the performance of improved broiler breeds in a Rwandan smallholder context, (b) farmer profitability, and (c) household consumption of broilers. With 18 months of flock data, average livability of flocks was $89 \%$, similar to large-scale, modern broiler sector averages globally. Tworore Inkoko smallholders have been profitable, with average profit increasing as they gain experience and grow-out new flocks (profit ranging between 28 and 89 USD per flock). Birds set aside for consumption by farmers ranged from an average of 0.31 to 4.00 birds per flock, settling at closer to three per flock by the end of the first 18 months. Smallholder farmers in Rwanda have the potential to be successful through this model. Lessons learned from the rollout of this pilot project will be used to inform potential scale-up of this hybrid model across Rwanda, as well as other pro-poor value chains looking to increase food security by generating incomes and increasing access to highly nutritious and balanced diets.
\end{abstract}

Key words: household nutrition, food security, poultry, sustainable intensification, public-private partnership 


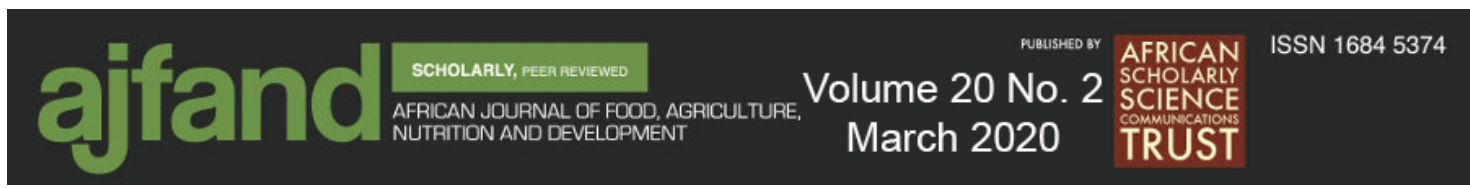

\section{INTRODUCTION}

Since the 2007/2008 global food price crisis, there has been an increased interest in improving food security through nutrition-focused projects throughout Africa that include income-generating components [1]. The pilot project, Tworore Inkoko, Twunguke (TI) (Kinyarwanda for "Let's raise chickens and make a profit"), seeks to meet these goals in a pro-poor value chain development aimed at training and supporting smallholder farmers in the rural district of Musanze, Rwanda through the sustainable intensification of broiler production.

According to the Comprehensive Africa Agriculture Development Programme (CAADP) Framework for African Food Security (FAFS), food insecurity challenges must address the link between markets and nutrition, including supply, marketing, incomes of the vulnerable, and dietary diversification [2]. This is especially important in Rwanda, where the availability of calories has paralleled human population growth, but $60 \%$ of households remain "food insecure" or "marginally food secure" [3]. More specifically, the supply of highly digestible and complete protein, fats, and micronutrients of good bioavailability remain insufficient in the Rwandan diet [4]. Animal-sourced proteins include these essential micronutrients and, unlike plant-sourced proteins, contain significant amounts of the nine amino acids important for human diets. However, price and availability of chicken remain barriers to increased meat consumption among poor, rural households. A sustainable increase to the national supply of and access to animal-sourced protein, through broiler production, provides an opportunity to address these human nutrition needs $[5,6]$.

Rwanda's Ministry of Agriculture and Animal Resources (MINAGRI) recognizes the increasing demand for animal-sourced protein at the national level and has called for increased investment in the poultry value chain [7]. This Ministry has further suggested that semi-commercial smallholder poultry production (200-500 broilers) may be ideal for Rwanda [8]. To achieve this, Rwanda needs sustainable integrated farming systems that include economic, social, and environmental well-being to meet the nutritional and caloric needs of its rapidly rising population. Broiler production is well positioned to address the critical need for animal-sourced protein in human diets. Chickens have short production cycles, among the lowest feed conversion ratio of all livestock and also require little space. This is important for a country characterized by high population density, and steep hillsides.

Recent estimates indicate that there are 0.97 million broilers in Rwanda, with a targeted increase of $149 \%$ by 2022 through an increase in the scale and number of broiler operations [9]. However, the Strategy \& Investment Plan to Strengthen the Poultry Industry in Rwanda identifies major constraints to strengthening the poultry industry nationally, including: poor condition of village poultry, limited national supply of dayold chicks, challenges with availability, quality and price of poultry feed ingredients, bird health constraints, absence of marketing strategies, limited access to credit, and institutional constraints [7]. Public and private investments, both domestic and foreign, are working to address these challenges using a wide variety of approaches. 


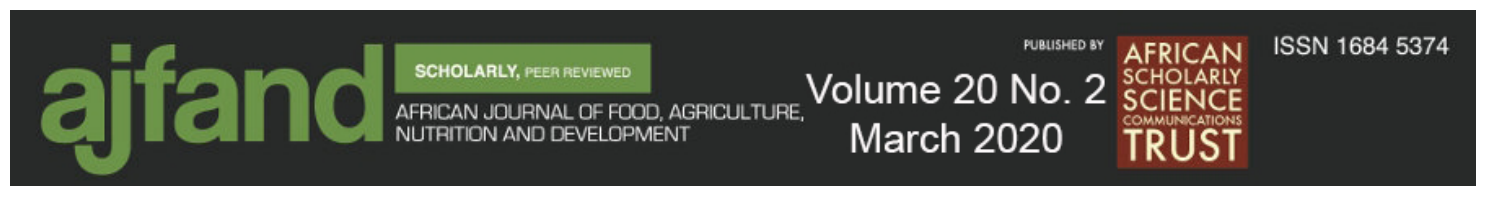

Globally, the poultry sector is moving to intensive, confined, larger-scale production approaches. These improved systems, including modern broiler genetics and concerted biosecurity infrastructure, support productivity and disease control, for both birds and humans [10]. However, concerns about the smallholder being 'left behind' remain [11]. Mottet and Tempio argue that the poultry sector must respond to the demand for meat and eggs, as well as supporting economic opportunities for smallholders [12]. Increasing smallholder poultry production requires the establishment of poultry networks, in addition to well-designed and implemented information dissemination programs [13, 14]. As such, hybrid models - those which use intensive, commercial principles at the household level - may best address the nutritional and economic needs of rural smallholders, as well as contribute to national poultry value chains.

This paper examines the evidence from the first eighteen months of piloting one such hybrid model in Rwanda TI. The following critical questions are addressed to understand the ability of this poultry model to successfully increase incomes and diversify diets in Rwanda:

i) Can Rwandan smallholders achieve livability averages similar to advanced, large-scale broiler operations using improved broiler breeds?

ii) Can smallholders generate income on broiler sales?

iii) Will smallholders and their households set aside broilers for consumption?

\section{USAID Feed the Future Tworore Inkoko, Twunguke}

The USAID Feed the Future Tworore Inkoko, Twunguke program leverages publicprivate support to intensify broiler production for smallholder farmers in northern Rwanda to: (a) increase incomes of rural smallholders, and (b) improve household nutrition outcomes through the consumption of chicken meat. Using an innovative private-sector-based train-the-trainer model, over a three-year and nine-month period, the program will train 750 smallholder farmers in Musanze District, northern Rwanda, in efficient broiler production. Customized for the Rwandan context, the program trains farmers to raise 100 birds per 6-week production cycle in an enclosed coop of 100 square feet. By the end of March 2019, 386 smallholders had been trained. Of these smallholders, 272 had coops constructed and 205 had harvested at least one flock of birds.

The model (Figure 1) employs a multi-faceted approach to recruitment, training, and support of smallholders in the program. Targeted toward the poorest and most vulnerable households (Ubedehe 1 and 2), TI's multi-stage recruitment process results in farmer cohorts of around 30 individuals. The recruitment process begins with a public information session, from which interested individuals are randomly selected to attend an information session and schedule a home visit to confirm a suitable coop location. Individuals who remain interested are then invited to a three-day intensive Farmer Training Program, which includes training modules on biosecurity, broiler management, record keeping, and household nutrition. Upon completion, enrolled farmers receive regular technical visits from the project staff. At the end of the grow-out cycle, farmers 


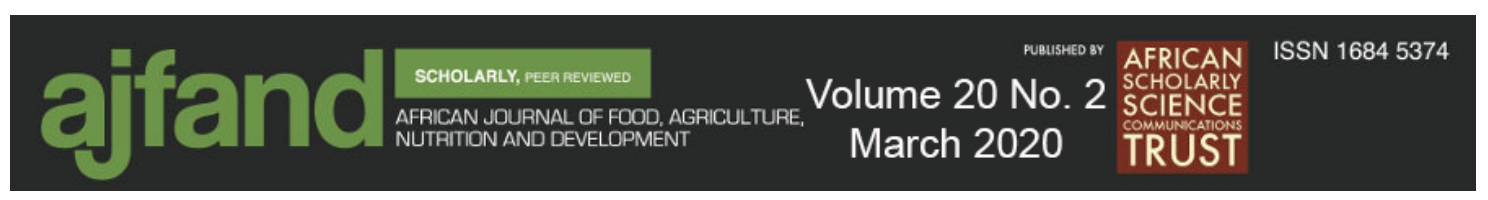

are offered a guaranteed broiler buy-back and are encouraged to keep chickens for household consumption.

Tworore Inkoko farmers receive two types of credit assistance to cover production costs for the program. First, farmers receive a zero-interest loan for all one-time expenses for set up (approximately 600 USD), including the coop building itself and the coop equipment (drinkers, feeders, clay pots for heating the coops). The second line of credit covers recurring expenses for each production cycle. These recurring expenses (approximately 300 USD per flock) include day-old chicks, feed, litter, disinfectant, charcoal (for heating the coops, especially in the first 14 days), and vaccines. All of these inputs (both initial set-up infrastructure and recurring inputs) are provided to each enrolled farmer by the TI project. Farmer coops are built by a local contractor, who builds each coop to the same specifications. The TI project staff deliver day-old chicks, feed and other recurring inputs to each farmer at the start of each cycle. Finally, the project guarantees to harvest and sell the enrolled farmers' chickens, and also calculates a farmer's payment based on the revenue from the sale of his/her flock, minus the recurring expenses' line of credit.

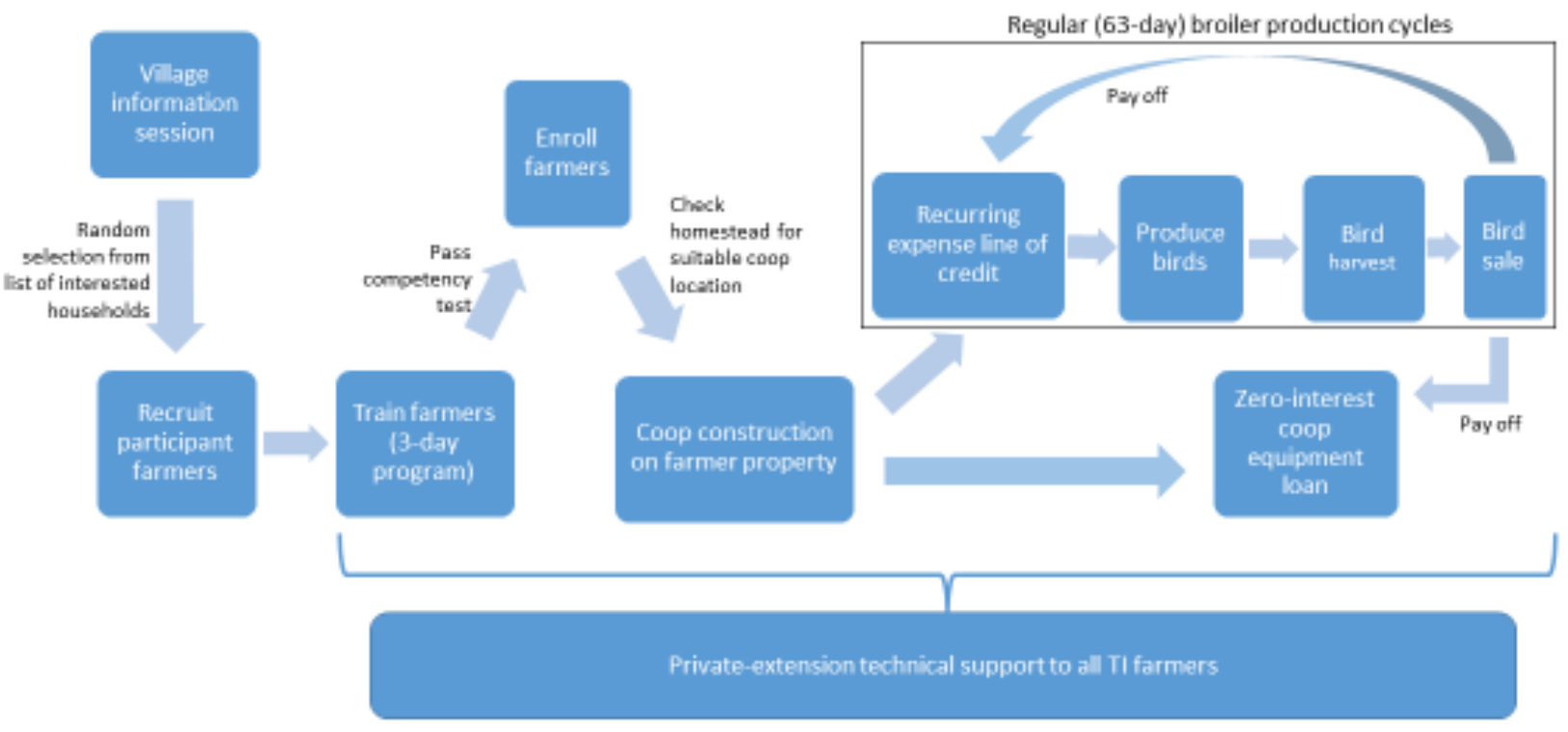

Figure 1: Tworore Inkoko, Twunguke smallholder broiler production model

As of March 31, 2019, TI has trained and enrolled 12 cohorts with a total of 210 female and 176 male TI producers. Table 1 provides additional enrollment details. About $82 \%$ of farmers have successfully completed the training and passed the competency test to be enrolled as a TI farmer; this is the same rate among men and women for the project as a whole. The competency test screens to ensure enrolled farmers are prepared to keep high production standards, as well as reinforce the perception among communities that the TI program wants serious participants. To date, only two farmers were dismissed after written warnings due to poor performance or not adhering to training protocols 


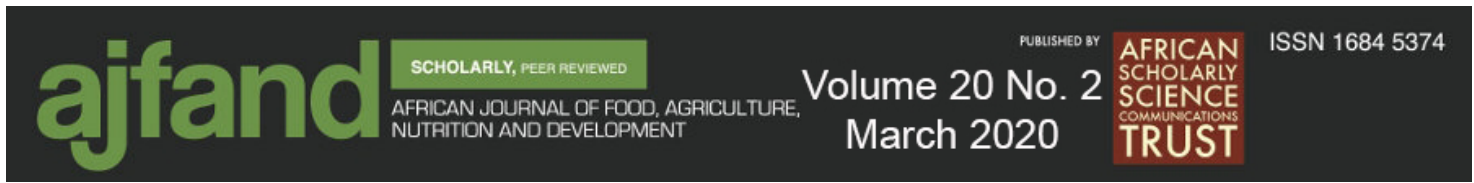

during production. As such, the program has an extremely high retention rate (99\%) over the first 18 months.

\section{Target population and region}

Tworore Inkoko targets rural smallholder households in Musanze District. Musanze is located in the Northern Province, bordering Uganda and the Democratic Republic of Congo. Musanze has a population of 368,000 (2012 census) and is representative of the densely populated smallholder rural areas and poverty rates across Rwanda [15]. In addition, Musanze has been identified by the Government of Rwanda as a district with slightly higher than average levels of undernourishment [15]. Furthermore, Musanze is the location of Rwanda's first commercial feedmill, Zamura Feeds Ltd., located just outside Ruhengeri town, and the Northern Province has a high concentration of layer operations. This makes Musanze a strategic location in terms of operations, as well as in terms of improving nutrition and income outcomes for smallholder households.

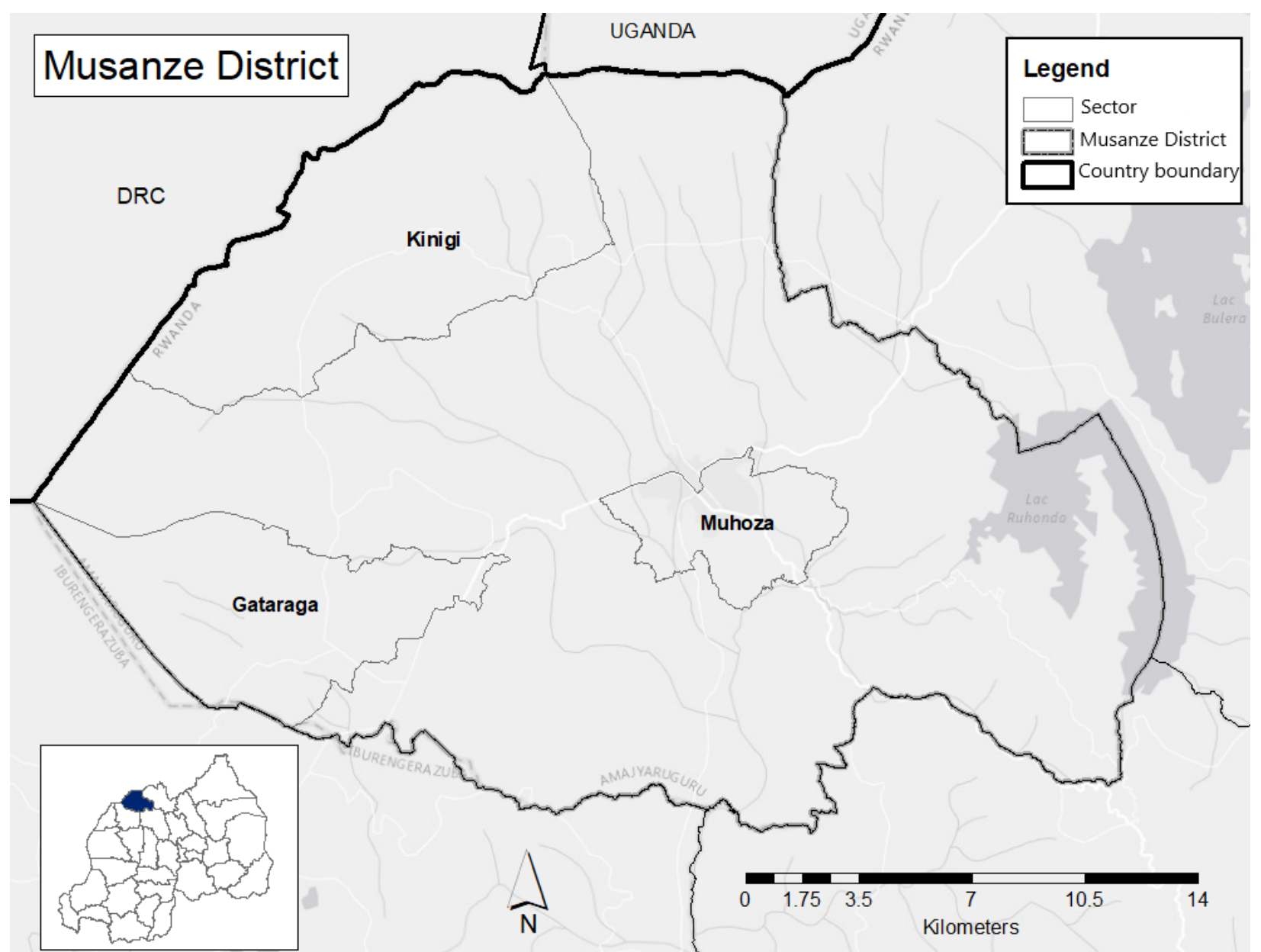

Figure 2: Map of Musanze District and Tworore Inkoko selected sectors (insert: location of Musanze District in Rwanda) 


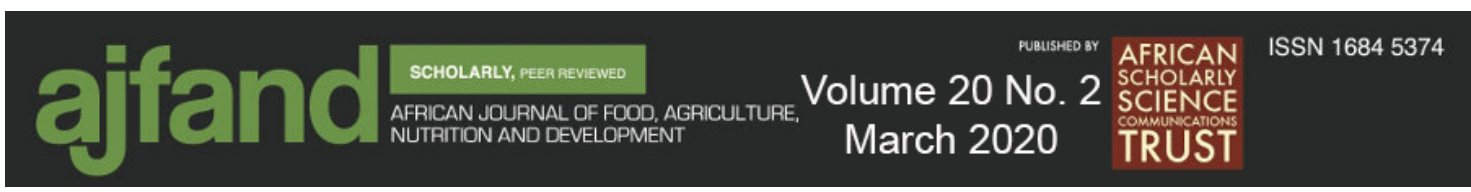

\section{MATERIALS AND METHODS}

Data were obtained from TI farmer enrollment, production records, and sales records beginning on September 15, 2017 (first chick placement) through March 31, 2019, recorded by the farmer's ID number. During each cycle of chickens, the project tracks flock records, which include recurring expenses (chicks, litter, feed, disinfectant, charcoal and vaccines), harvest numbers and weights, sales (live and/or processed birds), farmer revenue, and number of birds set aside for home consumption. All data are entered into the TI database, run through Microsoft SharePoint.

\section{RESULTS AND DISCUSSION}

\section{i) Broiler livability}

The TI hybrid broiler model uses modern genetics broilers and intensive commercial production approaches at the smallholder household level. Broiler livability serves as an indicator of smallholder farmers' ability to achieve the quality production standards of large-scale models. Overall, broiler livability -- percentage of birds surviving to harvest age -- is reliant on factors such as chick quality, biosecurity, temperature management, vaccination, and securing birds in a locked, single entry point coop to reduce instances of theft.

Tworore Inkoko uses Ross 308 from locally-based hatcheries as it is the only modern genetics broiler currently available in Rwanda, and is a fast-growing, feed-efficient, and high-yielding meat bird. In addition, this bird is characterized by softer meat, lower price, and is more appealing to the tourist/expatriate market compared to traditional, dualpurpose birds. On average, it takes around 48 days for fast-growing chickens to reach market weight while it takes around 80 days for slow-growing chickens [16]. With up to five grow-out cycles (flocks) per year, farmers have more regular and robust cash flow opportunities than through dual-purpose poultry models.

Large-scale, industrialized broiler systems achieve average livability of $90 \%$ or above [17] by heavily enforcing biosecurity protocols and regulating temperature with propane brooders and automated fan ventilation. In the first 18 months of the TI project, livability averaged $89 \%$-- comparable to these large-scale, industrialized broiler systems. Overall, TI flocks largely remained above the 90\% livability expectation (12 of the 18 months; Figure 3). One of the main reasons for the high livability of the project's birds is the heavy emphasis on biosecurity placed on all aspects of the TI program. Biosecurity is built into the design of the program through the implementation of standard size 100 square foot closed coops with a single access entry door. This biosecurity design is then enhanced through training TI farmers in biosecurity protocols, and throughout the continual engagement these farmers have with TI broiler technicians during and between production cycles.

Adhering to strict biosecurity protocols are a requirement of maintaining enrollment in the TI program. These protocols include: i) only one person in the coop at a time; ii) mandatory use of coop footwear; iii) elimination of all other poultry kept by a household prior to coop construction, and maintaining TI program birds as the only poultry raised 


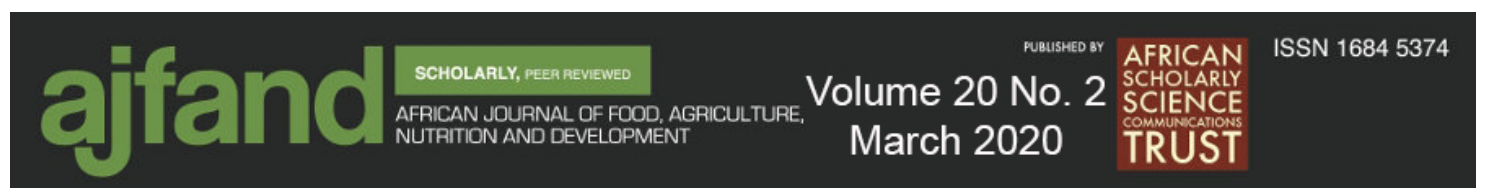

by an enrolled household; iv) a minimum of 14-days between cycles to reduce pathogen load; v) no other birds ever put in the coop except for those delivered by the TI program; vi) coops kept locked at all times and keys kept where only enrolled TI farmer and one or two trusted household members know.

The majority of farmers adhered to these rules, resulting in high bird livability at harvest. Two farmers who broke protocol (v) above were ejected from the TI program due to a breach of contract. The removal of these farmers and the subsequent deconstruction of their coops helped to reinforce the high priority placed on adhering to biosecurity protocols to maintain high livability rates and farmer success.

The highest mortality occurred between November 2018 and January 2019, when livability ranged between 81.1 and $85.3 \%$. In October 2018, TI switched to pelletized feed. Consumption of pelletized feed (rather than mash feed) enables broilers to reach target weight more quickly due to the efficiency of feed delivery. However, several farmers at elevations above $2000 \mathrm{~m}$ experienced bird mortality of more than $30 \%$ during the fifth week of bird growth due to ascites (fluid in the abdomen). The lower oxygen availability at these higher elevations meant that several birds in a flock were growing too fast vis-a-vis their vital organ development. In December 2018, TI technicians asked these farmers at higher elevations to switch back to the original mash feed. As a result, the February 2019 bird harvests returned to approximately $90 \%$ bird livability.

Minor variations between 90 and 95\% livability have been primarily caused by fluctuation in day-old chick quality, an issue of sourcing chicks in Rwanda, and new farmers' ability to maintain proper temperatures in the first two weeks of brooding when farmers must tend to their charcoal brooders every couple of hours, day and night.

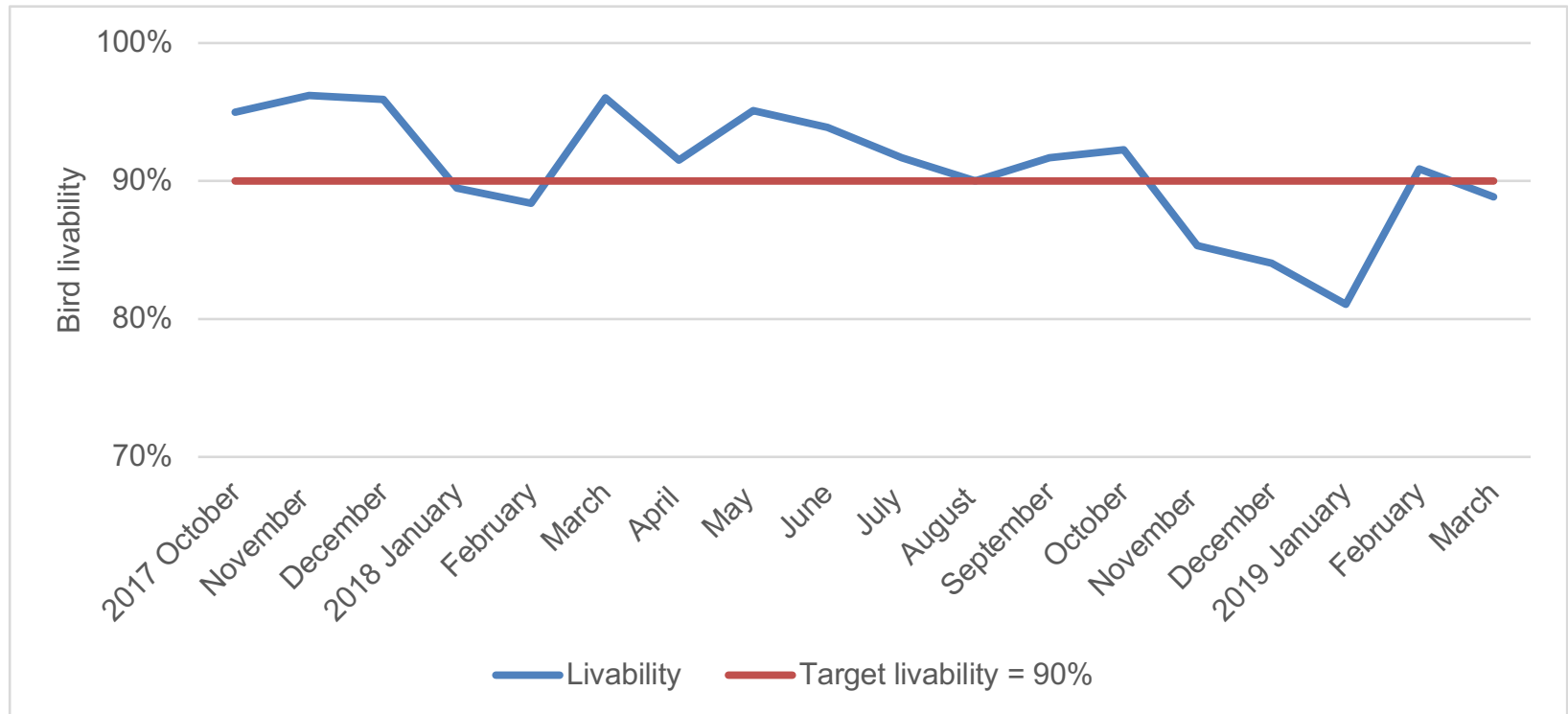

Figure 3: Average livability (\%) of broilers raised by Tworore Inkoko farmers 


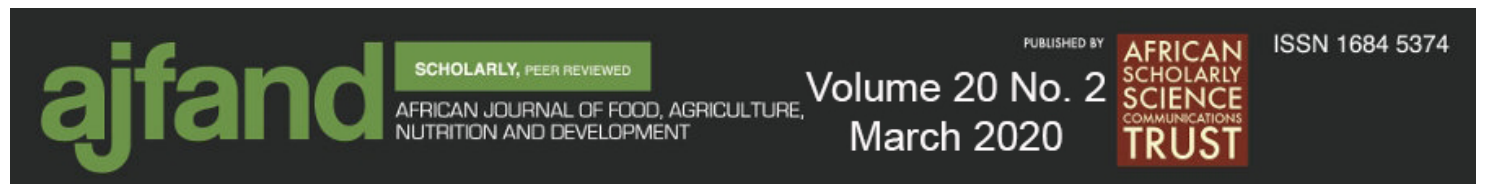

\section{ii) Farmer revenue}

Tworore Inkoko farmers experienced varying profits across the first 18 months of the project, ranging between 28 and 89 USD (RWF 25,000 and 80,000) per flock. Prices of chicken per live kg fluctuated between 1.33 USD (RWF 1,200) (December 2018) and 1.91 USD (RWF 1,718) (August 2018) (Figure 4). Sales of TI broilers have been occurring throughout the project, which aggregates birds of harvest age (typically 42-49 days) and sells to a range of consumers, including hotels, restaurants, traders, supermarkets and individuals. The project staff use vehicles from Zamura Feeds to collect and deliver birds from producers to either a local processor or live markets. The project staff also collect dressed whole birds post-processing and delivers them to dressed markets, including through the TI storefront location in Kigali. Live and dressed markets are sourced by the TI marketing team throughout Rwanda; the largest broiler markets in Rwanda are in Kigali and Gisenyi.

Farmer profit is maximized by high sales prices at the time of harvest and low cost of production throughout the production cycle. While commercial feed purchases comprise the largest proportion of broiler enterprise costs, farmers are able to secure positive net revenue from broiler production, similar to other smallholder broiler production across sub-Saharan Africa $[18,19,20]$. The TI team learned the best methods to train and support farmers during the first three months of production for high livability and low cost of production to maximize farmer revenue. While the initial design of the training program remains largely unchanged, the broiler technicians learned where farmers needed the most emphasis and follow-up, and farmer profits steadily rose.

The broiler sales in December 2017 were characterized by a strong demand for chicken around the Christmas holiday. However, market demand dropped early in the year (January - February 2018). While farmer profits rose in March 2018, the national demand for broilers dropped in April, primarily corresponding with the Rwanda Genocide Commemoration activities and Easter holidays. In May and June 2018, TI hired two sales people who specifically focused on identifying buyers in the Northern Province, and in Kigali. By late November 2018, other broiler enterprises across Rwanda increased poultry production to meet the seasonal holiday demand and prices decreased. Prices remained low again through February 2019 before rising again in March 2019 (Figure 4). 

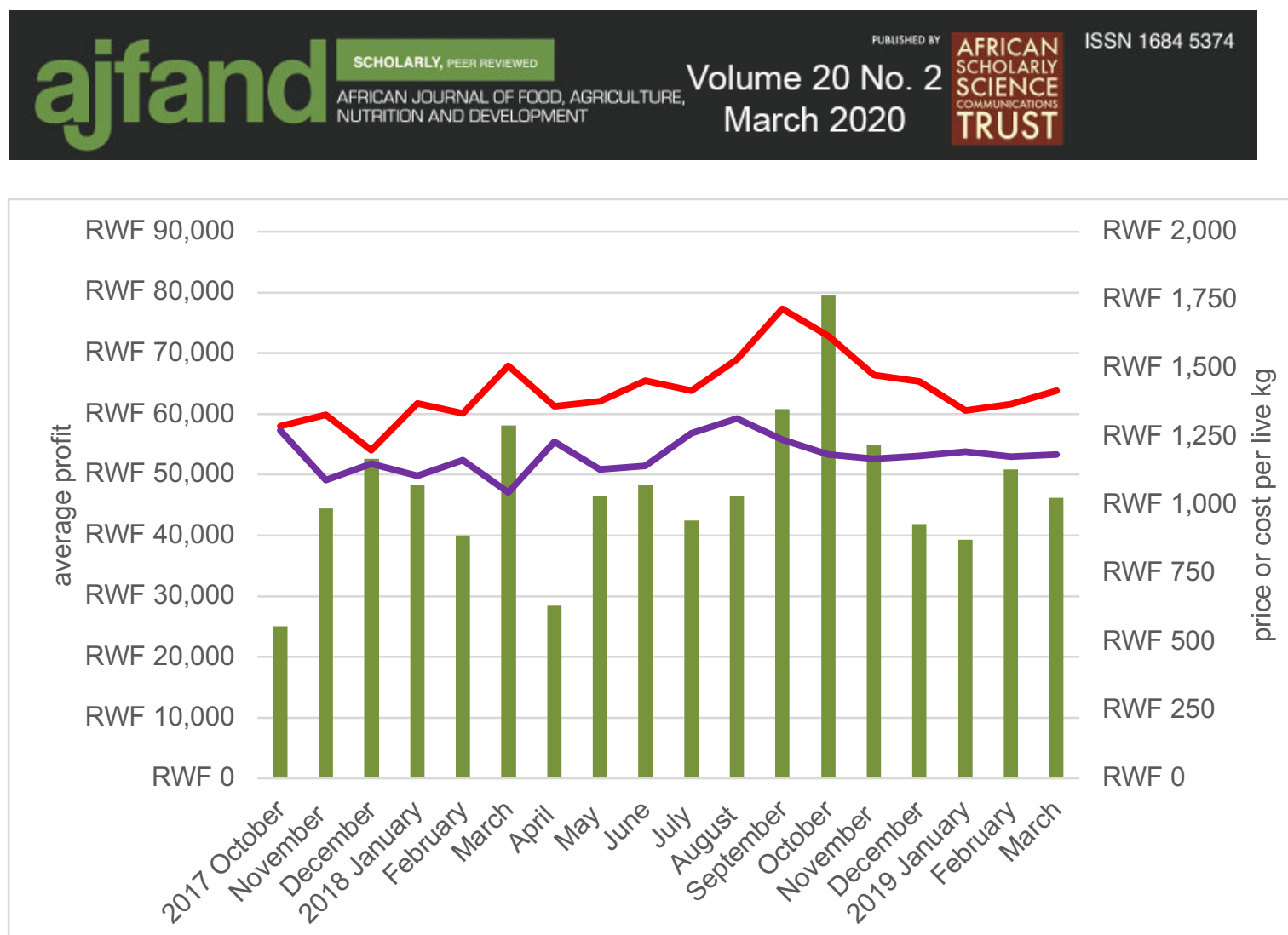

Net Average Profit per farmer per flock $\longrightarrow$ Sale Price (RWF/ live kg) $\longrightarrow$ COP (RWF/ live kg)

Figure 4: Farmer net average profit per flock versus sale price and cost of production (COP)

Cost of production fluctuated between 1.16 USD (RWF 1,046) and 1.46 USD (RWF $1,316)$ per live $\mathrm{kg}$ in the first year of the TI project, fluctuating as farmers enrolled and produced their first flocks. As farmers gained experience, cost of production stabilized in the last six months of the 18-month period (October 2018-March 2019), ranging between 1.30 USD (RWF 1,168) and 1.33 USD (RWF 1,194) per live kg of bird produced. Overall improvement in broiler husbandry practices helped drop the cost of production for farmers, resulting in increased farmer revenue through mid-November 2018. While there were fewer farmers who raised five or more flocks (Figure 5), initial results indicate that there is distinct improvement in average gross profit per flock with experience.

Tworore Inkoko farmer revenue is most influenced by individual husbandry techniques, as well as broiler market variations. While TI farmers are not mandated to sell their birds back to the project, the opportunity to do so helped them to maintain a certain level of farmer profitability. It is important to note that while TI farmers may be profitable, a greater understanding is needed to determine how their poultry activities have affected other livelihood activities. Additionally, while evidence shows that income is coming into the household, little is known about household decision-making and power over these new financial resources. Anecdotal evidence from TI technicians suggest that some men in a household will maintain full control over how the income is spent, even if a female in the household is the primary farmer. 

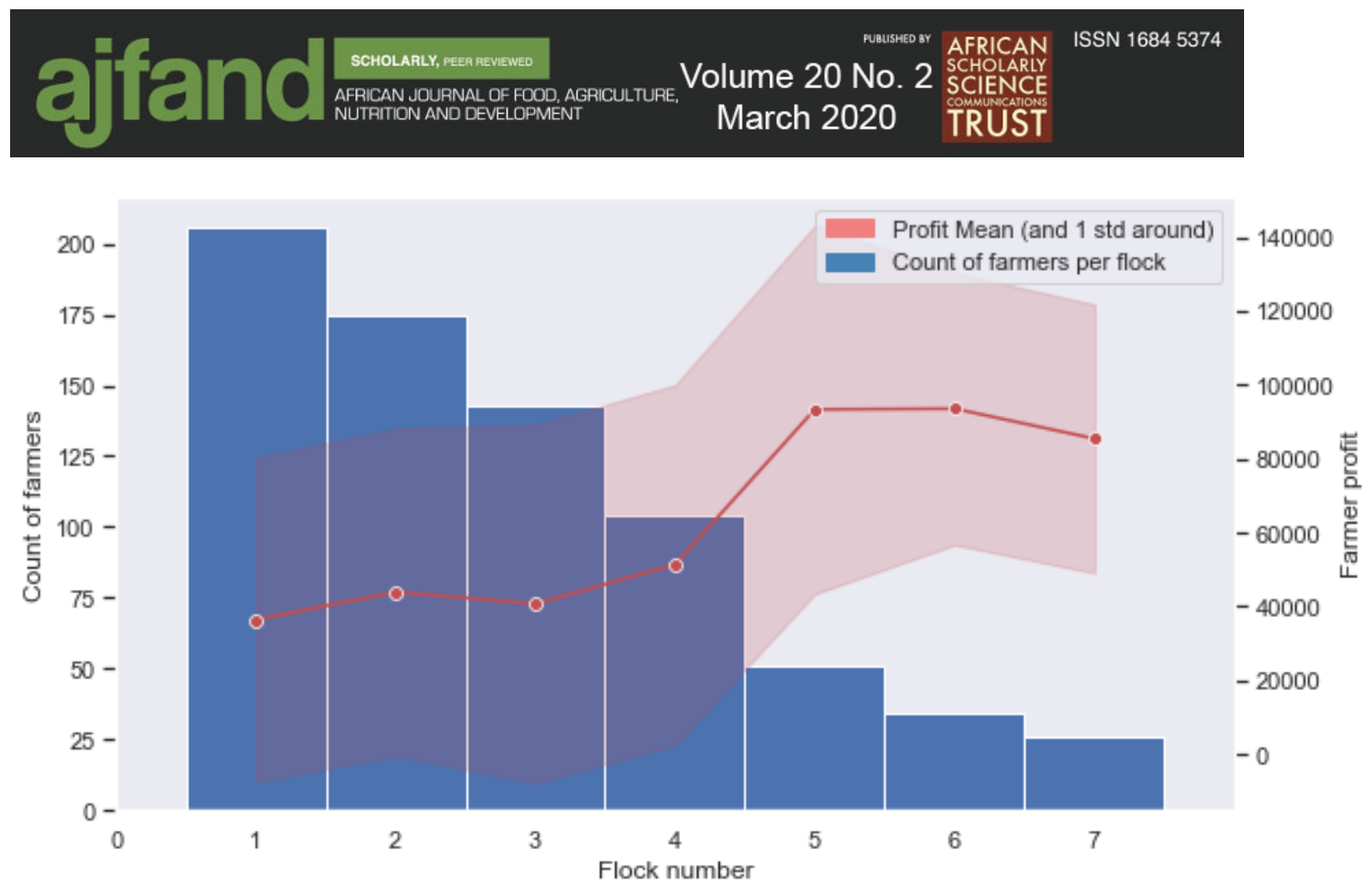

Figure 5: Count of farmers per flock number

\section{iii) Consumption of broiler meat}

The success of Tworore Inkoko also depends on increasing dietary diversity through the consumption of animal-sourced protein. A useful indicator of this is the number of birds which farmers retain for household consumption. At each harvest, farmers select the number of broilers they want to keep. Farmers set aside for home consumption an average of 0.31 (December 2017) to 4.00 (August 2018) birds per 100-chick flocks. Anecdotal information indicates that birds set aside are either processed at home and consumed in the farmer's home, gifted to neighbors, or given to peer farmers, who will then give a chicken back once he or she harvests his/her own flock.

In the first months of the project, the training and broiler technician visits strongly encouraged farmers to keep at least one bird each cycle for consumption. While there was some early interest in eating the chickens, farmers' interest in setting aside the birds for consumption dropped as the sales price rose in December 2017. In February 2018, the TI team re-stressed the importance of keeping chickens for household consumption, particularly for women of reproductive age and children under five years of age. By April 2018, birds set aside for consumption had risen to an average of 1.5-2.0 chickens per flock.

In May 2018, TI implemented hands-on interactive nutrition training to support increased consumption of birds among program participants. These half-day training sessions consist of a lesson on the importance of dietary diversity and animal-source protein consumption, a shopping activity to budget for chicken, eggs, or other proteins, as well as cooking and sharing a balanced meal that includes chicken. During this training, TI farmers are encouraged to share chicken meat with every member of their household. Following the training, average consumption of broilers increased to a peak of 4.0 birds per flock by August 2018. As prices of birds increased in September 2018, consumption 


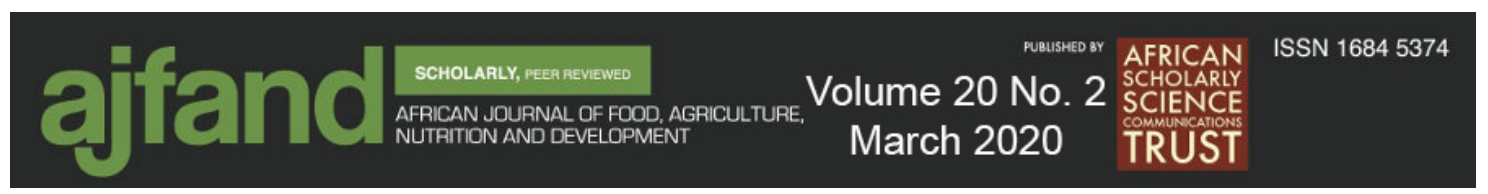

once again decreased, but stabilized between October 2018 and March 2019 at approximately 2.5-3.0 birds per flock.

Given that bird consumption is an indicator of increased animal-source protein in the household, it is important to consider nutrition education factors that may have influenced the findings. Previous studies highlight the positive relationship between owning livestock and improved diets $[21,22]$. In addition to owning livestock, nutrition education at the household level has been shown to enhance family nutritional outcomes $[23,24]$. Given the peaks of TI household bird consumption during periods of increased nutrition education and promotion activities, this highlights the potential impact these nutrition education interventions may have on household diet.

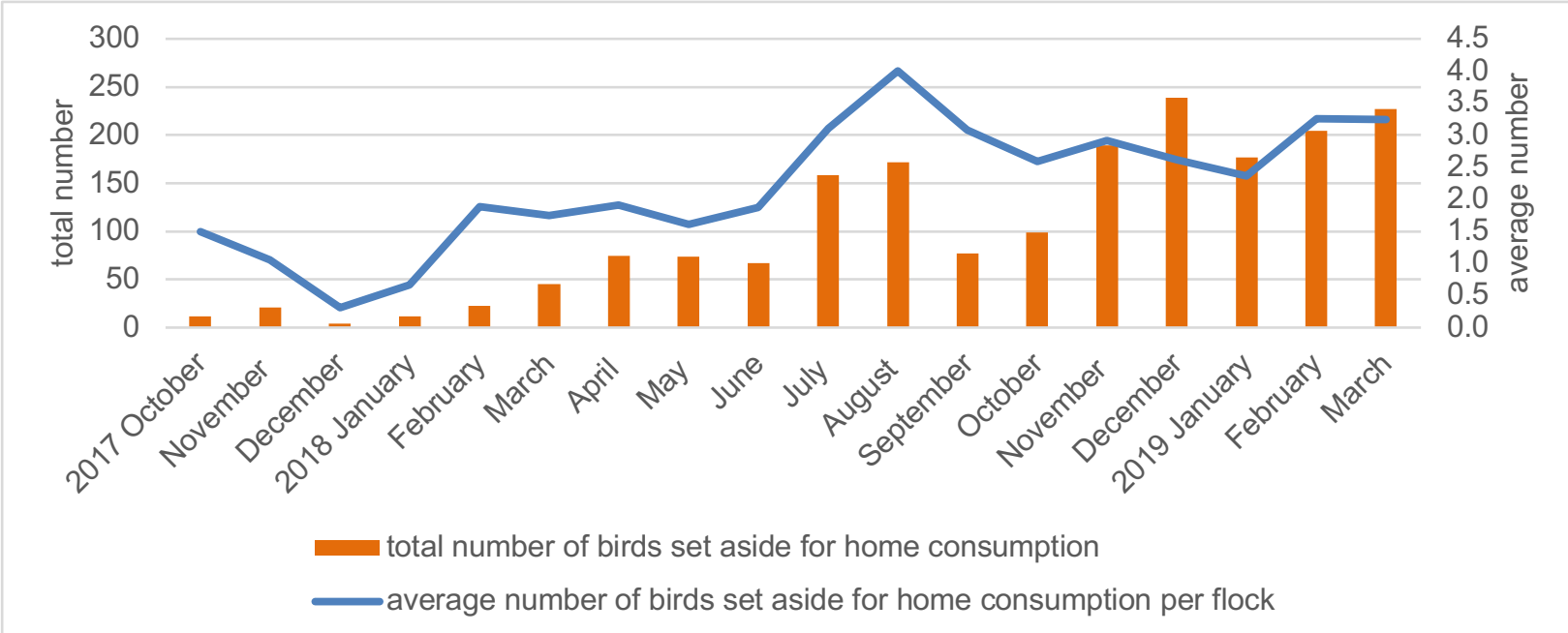

Figure 6: Broilers set aside for home consumption by Tworore Inkoko farmers

\section{CONCLUSION}

Through the first 18 months of program observations, results suggest that the TI hybrid model supports commercial farming among smallholder famers in a way that increases incomes and diversifies diets. By adequately training and supporting farmers in effective broiler husbandry, the majority of participants have successfully maintained high livability, generated profit and consumed chicken meat. For most months of production, TI flocks have remained above the $90 \%$ livability expectation. On average, farmers are making around RWF 47,000 (USD 52), with 3\% of farmers making as much as RWF 100,000 (USD 111) or more per flock. On average, TI farmers keep three chickens per 100-bird flock for consumption.

As the program continues to enroll more producers in Musanze, further research will improve the understanding of the long-term impacts related to household decisionmaking around income and diet. Focus groups and an annual household survey will be used to collect further data to assess the success of this model. As the initial period shows, technical assistance and training provide critical support to enrolled farmers as they learn efficient production techniques, improving profit, and to consume chickens, improving household nutrition. 


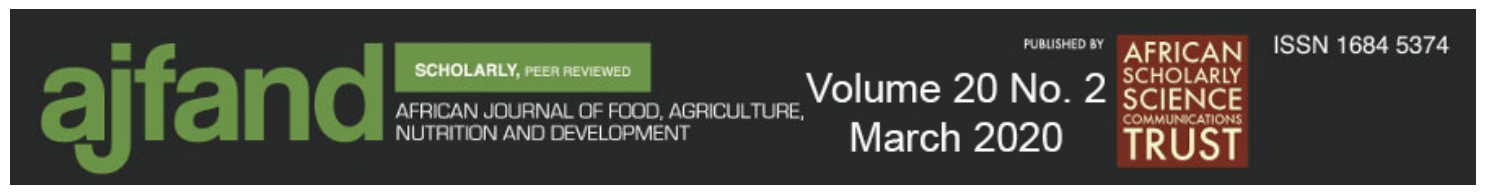

As the program considers scaling-up throughout Rwanda, TI must consider the logistical challenges to supply, support, and harvest 100-bird flocks. Lessons from this program suggest that the largest challenges to success may remain outside of the smallholder farmers' control, on either side of the poultry value chain. Nationally, growth targets for the poultry value chain are at an all-time high in Rwanda; however, existing constraints have been identified and are being addressed nationally [7,9]. At the supply end of the chain, one of the challenges to the TI program has been consistent and reliable sourcing of quality day-old Ross 308 chicks. Other inputs, particularly charcoal (for brooding) and poultry feed, are susceptible to price fluctuations and account for the largest expenses toward grow-out, thus placing the most stress on producers [25]. Tworore Inkoko has started to source chicks from multiple hatcheries, as well as looked into bulk purchases of lower cost feed, to increase the sustainability of this model.

Additionally, post-harvest resources are limited in the Rwandan poultry value chain. Maniriho and Bizoza have called for government and development agencies to build structures that help stabilize and assure markets for farmers, such as contract farming schemes [26]. While the TI program offers a guaranteed buy-back of birds from the farmers at harvest time, challenges remain related to the seasonality of market demand, processing and cold-chain logistics, and broiler marketing strategies. With better understanding of bird markets across Rwanda, TI can tailor the number of birds and the type of post-harvest direction (n other words processed vs live) according to market demands and revenue opportunities.

In response to the need for food security programs to address both nutrition and income objectives, TI's pro-poor value chain program sustainably intensifies production of broiler chickens in Rwanda. The hybrid model allows for specialization in the value chain, while considering the economic, social and environmental context of Musanze. However, training and supporting farmers is not enough when considering scaling of such a program. Expansion must also be considered at both ends of the value chain to maintain farmer profit and household dietary diversity.

\section{ACKNOWLEDGEMENTS}

This manuscript is made possible by the generous support of the American people through the United States Agency for International Development (USAID). The contents are the responsibility of The University of Tennessee and do not necessarily reflect the views of USAID or the United States Government. This study was conducted with the financial support of USAID/Rwanda and the African Sustainable Agriculture Project (ASAP) Foundation as a Global Development Alliance, Tworore Inkoko, Twunguke (Let's raise chickens for profit). The research was led by the University of Tennessee Institute of Agriculture (USAID Cooperative Agreement No.: AID-696-A-17-00006) with a sub-award to Zamura Feeds Limited, Ruhengeri, Rwanda. 


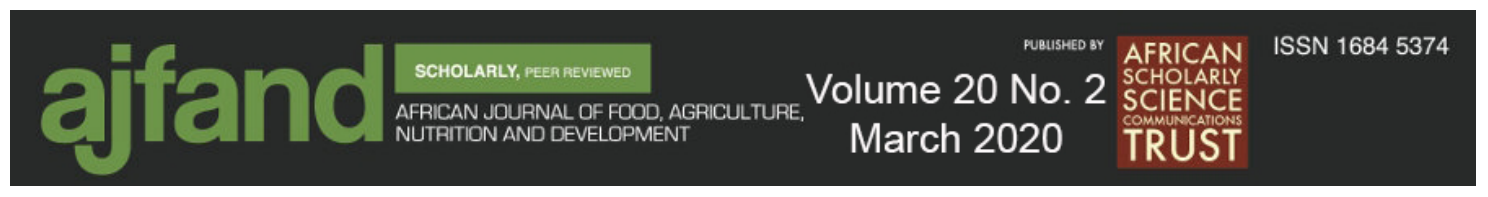

Table 1: Tworore Inkoko, Twunguke recruitment and enrollment (July 2017 March 2019)

\begin{tabular}{|ll|c|cc|cc|cc|}
\hline Cohort & Sector - cell & $\begin{array}{c}\text { Training } \\
\text { Date } \\
(\mathrm{MM} / \mathrm{YY})\end{array}$ & \multicolumn{2}{|c|}{$\begin{array}{c}\text { Number } \\
\text { Trained }\end{array}$} & \multicolumn{2}{c|}{$\begin{array}{c}\text { Officially } \\
\text { enrolled }\end{array}$} & \multicolumn{2}{c|}{$\begin{array}{c}\text { Percentage of } \\
\text { trained, enrolled }\end{array}$} \\
\hline 1 & $\begin{array}{l}\text { Muhoza and } \\
\text { Musanze } \\
\text { (pilot }\end{array}$ & $07 / 17$ & 14 & 12 & 14 & 12 & $100 \%$ & $100 \%$ \\
2 & cohort) & Mule & Female & Male & Female & Male & Female \\
\hline 3 & Gataraga 1 & $12 / 17$ & 16 & 17 & 15 & 15 & $94 \%$ & $88 \%$ \\
4 & Kinigi 1 & $02 / 18$ & 21 & 14 & 19 & 10 & $90 \%$ & $71 \%$ \\
5 & Gataraga 2 & $04 / 18$ & 26 & 11 & 20 & 4 & $77 \%$ & $36 \%$ \\
6 & Kinigi 2 & $06 / 18$ & 15 & 20 & 13 & 13 & $87 \%$ & $65 \%$ \\
7 & Gataraga 3 & $08 / 18$ & 25 & 7 & 16 & 6 & $64 \%$ & $86 \%$ \\
8 & Kinigi 3 & $10 / 18$ & 14 & 21 & 13 & 20 & $93 \%$ & $95 \%$ \\
9 & Gataraga 4 & $12 / 18$ & 31 & 23 & 26 & 21 & $84 \%$ & $91 \%$ \\
10 & Kimonyi 1 & $01 / 19$ & 13 & 41 & 12 & 31 & $92 \%$ & $76 \%$ \\
11 & Rubundi 1 & $02 / 19$ & 22 & 32 & 15 & 24 & $68 \%$ & $75 \%$ \\
\hline TOTAL & Cyuve 1 & $03 / 19$ & 8 & 38 & 6 & 34 & $75 \%$ & $89 \%$ \\
\hline
\end{tabular}




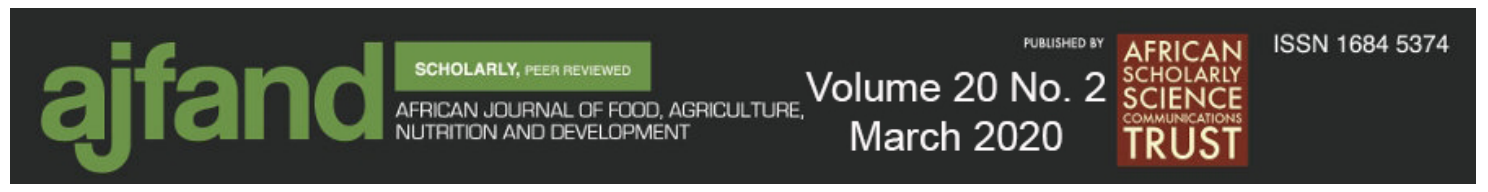

\section{REFERENCES}

1. Food and Agriculture Organization of the United Nations (FAO). Synthesis of Guiding Principles on Agriculture Programming for Nutrition. FAO, Rome, 2013.

2. Comprehensive Africa Agriculture Development Programme (CAADP). Pillar III: Framework for African Food Security. Comprehensive Africa Agriculture Development Programme, Midrand, 2013.

3. World Food Programme. Rwanda 2015: Comprehensive Food Security and Vulnerability. World Food Programme, Rome, 2015.

4. Save the Children. A Cost of Diet Analysis in a Northern Highland District of Rwanda. 2011. https://www.heacod.org > en-gb > Rwanda CoD Report 2011. Date Accessed: 21 August, 2019.

5. Murphy SP and LH Allen Nutritional Importance of Animal Source Foods. The Journal of Nutrition 2003; 133(11): 3932S-3935S.

6. Omamo SW, Gentilini U and S Sandström (Eds.). Revolution: From Food Aid to Food Assistance: Innovations in Overcoming Hunger. World Food Programme, Rome, 2010.

7. Ministry of Agriculture and Animal Resources (MINAGRI) Strategy \& Investment Plan to Strengthen the Poultry Industry in Rwanda. Ministry of Agriculture and Animal Resources. Rwanda Ministry of Agriculture and Animal Resources, Kigali, 2012a.

http://www.minagri.gov.rw/fileadmin/user_upload/documents/STRAT.PLC/POU LTRY_INDUSTRY_IN_RWANDA_Final.pdf. Date Accessed: 21 August, 2019.

8. Ministry of Agriculture and Animal Resources (MINAGRI). Strategic and Investment Plan to Strengthen the Animal Genetic Improvement in Rwanda. Final report. Rwanda Ministry of Agriculture and Animal Resources, Kigali. 2012b. http://www.minagri.gov.rw/fileadmin/user_upload/documents/STRAT.PLC/AGI Strategy_Rwanda-final-1.pdf. Date Accessed: 21 August, 2019.

9. International Livestock Research Institute. Rwanda Livestock Master Plan. International Livestock Research Institute, Nairobi, 2017. http://extwprlegs1.fao.org/docs/pdf/rwa172923.pdf. Date Accessed: 21 August, 2019.

10. Narrod CA and M Tiongco Global Poultry Sector Trends and External Drivers of Structural Change. FAO, Rome, 2012.

11. Mack S, Hoffmann D, and J Otte The Contribution of Poultry to Rural Development. World's Poultry Science Journal 2005; 61(1): 7-14. 


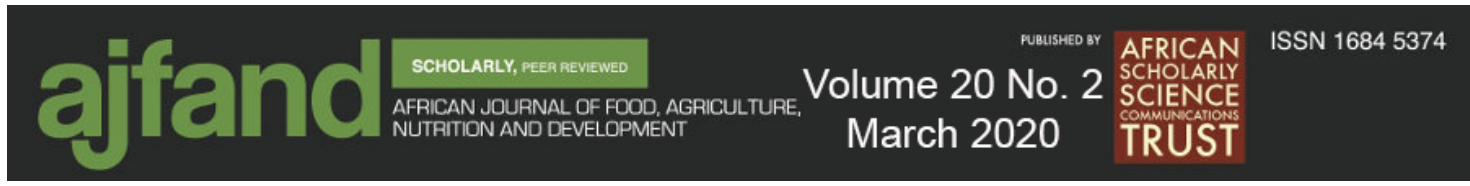

12. Mottet A, and G Tempio Global Poultry Production: Current State and Future Outlook and Challenges. World's Poultry Science Journal 2017; 73(2): 245-256.

13. Mbuza F, Manishimwe R, Mahoro J, Simbankabo $\mathbf{T}$ and $\mathbf{K}$ Nishimwe Characterization of Broiler Poultry Production System in Rwanda. Tropical Animal Health and Production 2017; 49(1): 71-77.

14. Guèye EF The Role of Networks in Information Dissemination to Family Poultry Farmers. World's Poultry Science Journal 2009; 65(1): 115-124.

15. National Institute of Statistics of Rwanda (NISR). District Profile: Musanze. National Institute of Statistics of Rwanda, Kigali. 2015.

16. Compassion in World Farming. The Welfare of Broiler Chickens in the European Union. Compassion in World Farming, Petersfield, 2005. ISBN 1 90015635 0. https://www.ciwf.org.uk/media/5235309/Welfare-sheet-Broilerchickens.pdf. Date Accessed: 21 August, 2019.

17. Rezaei M, Yngvesson J, Gunnarsson S, Jonsson $\mathbf{L}$ and A Wallenbeck Feed efficiency, Growth Performance, and Carcass Characteristics of a Fast- and a Slower-growing Broiler Hybrid Fed Low- or High-Protein Organic Diets. Organic Ag., 2018; 8: 121-128. https://doi.org/10.1007/s13165-017-0178-6

18. Baba MD, Dabai JS, Sanchi ID, Yakubu G and TA Manga Profitability of Smallholder Broiler Production in Bida Metropolis, Niger State, Nigeria. Agricultural Rural Development, 2016; 3: 1-5.

19. Oluwatayo IB, Machethe TA and MP Senyolo Profitability and Efficiency Analysis of Smallholder Broiler Production in Mopani District of Limpopo Province, South Africa. Journal of Agribusiness and Rural Development, 2016; 39(1): 145-154. doi: 10.17306/JARD.2016.17

20. Anang BT, Yeboah $\mathbf{C}$ and AA Agbolosu Profitability of Broiler and Layer Production in the Brong Ahafo region of Ghana. Journal of Agriculture and Biological Science, 2013; 8(5): 423-430.

21. Rawlins R, Pimkina S, Barrett CB, Pedersen S and B Wydick Got Milk? The Impact of Heifer International's Livestock Donation Programs in Rwanda on Nutritional Outcomes. Food Policy, 2014; 44: 202-213.

22. Hetherington JB, Wiethoelter AK, Negin J and SM Mor Livestock Ownership, Animal Source Foods and Child Nutritional Outcomes in Seven Rural Village Clusters in Sub-Saharan Africa. Agriculture \& Food Security, 2017; 6(1): 9.

23. Murendo $\mathbf{C}$, Nhau B, Mazvimavi $\mathbf{K}$, Khanye $\mathbf{T}$ and $\mathbf{S}$ Gwara Nutrition Education, Farm Production Diversity, and Commercialization on Household and Individual Dietary Diversity in Zimbabwe. Food \& Nutrition Research 2018; 62. 


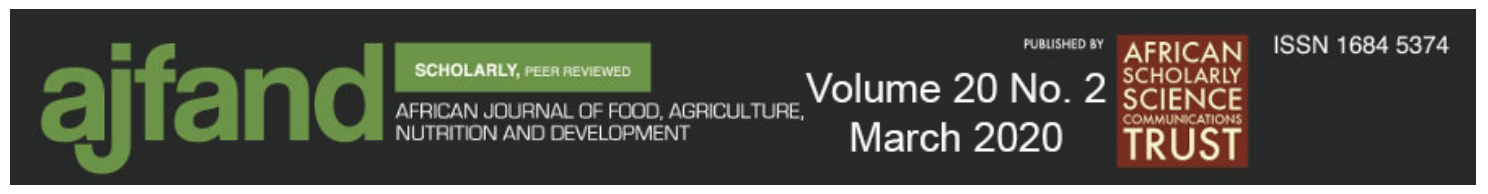

24. Walton C, VanLeeuwen J, MacLellan D, Taylor J and S Mbugua Effect of Nutrition Education and Dairy Group Membership on Nutrition Knowledge, Practices and Diet Quality for Rural Kenyan Farm Women. African Journal of Food, Agriculture, Nutrition and Development 2017; 17(3): 12343-12361.

25. Kenner B, Lambert D, Trejo-Pech C, Thompson J and T Gill Financial Risks in Rwandan Smallholder Broiler Production. Journal of Agribusiness in Developing and Emerging Economies. 2019 doi: 10.1108/JADEE-11-2018-0163

26. Maniriho A and AR Bizoza Determinants of Crop Production in Musanze District, Northern Rwanda. East Africa Research Papers in Economics and Finance, 2018.

https://ju.se/download/18.2304a3fb164265793121450f/1530153275832/EARPEF\%202018-36\%20Maniriho.pdf. Date Accessed: 21 August, 2019. 